\title{
METHODS OF TARGET RECOGNITION BASED ON CENTRAL IMAGE CHORD TRANSFORMATION
}

\author{
Veaceslav Perju*, ORCID 0000-0002-7755-4277 \\ Agency for Military Science and Memory, 47 Tighina Str., Chisinau, Republic of Moldova \\ *Corresponding author: Veaceslav Perju, vlperju@yahoo.com
}

Received: 09. 12. 2021

Accepted: 10. 19. 2021

\begin{abstract}
In the article the analysis of different approaches to invariant target recognition was made, such as based on the support vector machines, deep learning techniques, neural networks, generation of moment features, etc. It was determined that one of the perspectives approaches in target recognition suppose the use of the central and logarithmic central image chords transformations. There have been described the new methods of the target recognition, based on the central image chords transformation. Tasks of target recognition were formulated. New 4 methods of target recognition were described. It is presented the comparison of the different target's recognition methods regarding the processing stages number, realized operations, target's image normalization's operation, the operations realized in parallel, kind of the target's scale and rotation determination sequence, target's rotation determination approach.
\end{abstract}

Keywords: target, chord, transformation, recognition, processing stage, operation, spectrum.

Rezumat. În articol este prezentată analiza diferitelor abordări ale recunoașterii invariante a țintei, cum ar fi pe baza mașinilor vectoriale de suport, tehnici de învățare profundă, rețele neuronale, generarea de caracteristici ale momentelor ş.a. A fost determinat că una dintre direcțiile importante în recunoașterea automată a țintei se bazează pe transformări centrale și logaritmice centrale ale coardelor de imagine. Sunt descrise noile metode de recunoaștere a țintei, bazate pe transformarea centrală a coardelor imaginii. Sunt formulate sarcinile de recunoaștere a țintei. Sunt descrise 4 metode noi de recunoaștere a țintei. Este dată compararea diferitelor metode de recunoaștere a țintei în ceea ce privește $\mathrm{nr}$ de etape de procesare, de operațiuni realizate, de operațiuni de normalizare a imaginii țintei, de operațiuni realizate în paralel, privind secvenţa de determinare a scării şi rotației, abordarea determinării rotației țintei.

Cuvinte cheie: țintă, coardă, transformare, recunoaștere, etapă de procesare, operație, spectru.

\section{Introduction}

Invariant target recognition (ITR) is one of the important fields in military and civil applications, which suppose the real-time target classification independent of his position into the plane, rotation, scale, etc. In the articles [1 - 3] the approaches based on using the 
Support Vector Machines (SVM) in ITR are described. Another direction supposes the deep learning techniques used, which have been an important yet challenging research field in computer vision. In the research [4], a deep learning-based method was applied and a conditional random field is used to generate finer details. In the articles $[5,6]$ the ITR systems using the neural networks are described. The ITR based on the target's moment features is described in the articles [7, 8]. Unfortunately, the described approaches are complex in realization and need sufficient processing time.

One of the perspective approaches supposes the realization of the target's image chord transformation [9, 10]. The present article consists of the results of elaboration and investigation of the new target recognition methods, based on the central image chords transformation. In section 2 there are formulated the tasks of target recognition. In sections $3 \div 6$ there are described the new 4 methods of target recognition. In section 7 it is presented the comparison of the different target's recognition methods regarding the processing stages, realized operations, target's image normalization's operation, the operations realized in parallel, kind of the target's scale and rotation determination sequence, target's rotation determination approach.

\section{Tasks of target recognition and the operations realized in the target recognition methods}

Let the target be described via a continuous brightness function $\mathrm{P}(\mathrm{x}, \mathrm{y})$. Let under the influence of some distorting function DF, in the target's image can be introduced the noise and all points of the areas of $P(x, y)$ determination are changed by a certain law:

$P(x, y) \rightarrow D F[P(x, y)]=P^{\prime}\left(x^{\prime}, y^{\prime}\right)$.

In the presence of the shifts, angular rotation and scale distortions, the law of changes can be described by equations of a 4-parametric group of transformations [11]: $x^{\prime}=F_{1}[x, y, D F(x, y)]=\left\{e_{1}\left[x \cos \left(e_{2}\right)-y \sin \left(e_{2}\right)\right]+e_{3}\right\}, y^{\prime}=F_{2}[x, y, D F(x, y)]=\left\{e_{1}\left[x \sin \left(e_{2}\right)+y \cos \left(e_{2}\right)\right]+e_{4}\right\}$.

Here $e_{1}$ is a homothetics parameter, describing the scale change of the target's image; $e_{2}$ - parameter characterizing rotation of the target in the OXY plane; $e_{3}, e_{4}-$ are the target' shits of the in the plane relative to its reference position. In this case, the function $\mathrm{P}^{\prime}\left(\mathrm{x}^{\prime}, \mathrm{y}^{\prime}\right)$ can be represented as:

$P^{\prime}\left(x^{\prime}, y^{\prime}\right)=P\left(x+e_{3}, y+e_{4}, e_{1}, e_{2}\right)$.

Let describe the tasks of a target recognition as follows: target's image capture, classification of the target; target's space parameters determination - target's image scale $e_{1}$, his angular rotation $e_{2}$, and the target's in the plane position $e_{3}$ and $e_{4}$. These data will permit the organization of effective target tracking.

In the target recognition method described below, will be realized the next operations: PP - input target's image preprocessing; F - Fourier transform operation; $P$ - target's position in plane determination (parameters $\mathrm{e}_{3}, \mathrm{e}_{4}$ ); $\mathrm{N}$ - normalization of the target's image (centering on parameters $\mathrm{e}_{3}, \mathrm{e}_{4}$ ); $\mathrm{N} 1$ - target's image normalization on $\mathrm{e}_{1}$ and conversion to a polar coordinate system; N2 - target's image conversion to log-polar coordinate system; N3 normalization of the target's image (centering on parameters $e_{3}, e_{4}$ ) vie Fourier spectrum calculation; N4 - normalization of the target's image (centering on parameters $e_{3}, e_{4}$ ) and conversion to a log-polar coordinate system; N5 - target's image spectrum normalization on $\mathrm{e}_{1}$ and conversion to a polar coordinate system; N6 - normalization of the target's image (centering on parameters $\mathrm{e}_{1}, \mathrm{e}_{2}$ ) and conversion to a log-polar coordinate system; $\mathrm{T}$ - chord transformation of the centered target's image; CT1 - chord transformation of the target's 
image Fourier spectrum; C - classification of the target; $S$ - scale $e_{1}$ of the target determination; $\mathrm{R}$ - rotation $\mathrm{e}_{2}$ of the target determination; $\mathrm{S}, \mathrm{R}$ - target's scale $\mathrm{e}_{1}$ and rotation $\mathrm{e}_{2}$ determination in one step.

\section{Method TRM1 of target recognition}

The method TRM1 suppose the next sequence of operations: PP-F-P-N-CT-C-S-N1-R. Following this method, at the first stage, the input target's image is preprocessed. The target's image is enhanced, noise is removed, etc.

$$
\mathrm{P}^{\prime}\left(\mathrm{x}^{\prime}, \mathrm{y}^{\prime}\right) \rightarrow \mathrm{P}\left(\mathrm{x}^{\prime}, \mathrm{y}^{\prime}\right)=\mathrm{P}\left(\mathrm{x}, \mathrm{y}, \mathrm{e}_{1}, \mathrm{e}_{2}, \mathrm{e}_{3}, \mathrm{e}_{4}\right),
$$

At the second stage, the position of the target in the plane (parameters $e_{3}, e_{4}$ ) is calculated. In parallel, the target's image Fourier spectrum is calculated:

$$
P\left(x^{\prime}, y^{\prime}\right) \rightarrow\left|F T\left\{P\left(x^{\prime}, y^{\prime}\right)\right\}\right|^{2}=P\left(x^{\prime}, y_{1}^{\prime}\right)=P\left(x_{1}, y_{1}, e_{1}, e_{2}\right),
$$

were $\mathrm{FT}\{\ldots\}$ is the Fourier transform operation. The maximum frequency $\mathrm{f}_{\mathrm{m}}$ of the Fourier spectrum $P\left(x^{\prime}, y_{1}^{\prime}\right)$ and the target's image $P\left(x^{\prime}, y^{\prime}\right)$ complexity $S L$ [12] are determined.

The obtained function $P\left(x_{1}, y_{1}, e_{1}, e_{2}\right)$ will be not influenced by the parameters $e_{3}, e_{4}$, due to the properties of the Fourier spectrum [11].

On the third stage, based on the parameters $e_{3}, e_{4}$, and $S L$, the function $P\left(x^{\prime}, y^{\prime}\right)$ is centered:

$$
P\left(x^{\prime}, y^{\prime}\right)=P\left(x+e_{3}, y+e_{4}, e_{1}, e_{2}\right) \rightarrow P\left(x^{\prime} 2, y^{\prime}\right)=P\left(x_{2}, y_{2}, e_{1}, e_{2}\right),
$$

were $\mathrm{x}_{2}=\mathrm{x}-\mathrm{e}_{3}, \mathrm{y}_{2}=\mathrm{y}-\mathrm{e}_{4}$

On the fourth stage will be realized Central Image Chord Transformation (CICT) [10]:

$$
P\left(x_{2}^{\prime}, y_{2}^{\prime}\right) \rightarrow T\left\{P\left(x_{2}^{\prime}, y_{2}^{\prime}\right)\right\}=P\left(x^{\prime}, y_{3}^{\prime}\right),
$$

where $T\{\ldots\}$ - the operation of CICT. Based on the function $\mathrm{P}\left(\mathrm{x}_{3}^{\prime}, \mathrm{y}_{3}^{\prime}\right)$, will be formed a vector $\mathbf{v}$ of the target's features [11].

At the fifth stage, the target recognition will be made at the processing of the vector v. The classification algorithm is based on the Fisher criterion [11] using the combination of the target's features and forming a linear discrimination function for reference target's images of different kinds at arbitrary rotations, scale changes, etc.

On the sixth stage, the target's scale $\mathrm{e}_{1}$ is determined based on the expression:

$$
e_{1}=f_{m s} / f_{m} \text {, }
$$

where $f_{m s}$ is the Fourier spectrum's maximum frequency of the standard target, the class of which was determined on the previous stage.

On the seventh stage, the function $\mathrm{P}\left(\mathrm{x}_{2}^{\prime}, \mathrm{y}_{2}^{\prime}\right)$ is normalized on $\mathrm{e}_{1}$ and transformed to a polar coordinate system:

$$
P\left(x_{2}^{\prime}, y_{2}^{\prime}\right)=P\left(x_{2}, y_{2}, e_{1}, e_{2}\right) \rightarrow P\left(x_{4}^{\prime}, y_{4}^{\prime}\right)=P\left[x_{4}+x_{40}\left(e_{2}\right), y_{4}\right],(3,6)
$$

were $x_{4}^{\prime}=\operatorname{arctg}\left(y_{2} / x_{2}\right), y_{4}^{\prime}=\left[\left(x^{2}{ }_{2}+y^{2}{ }^{2}\right)^{1 / 2}\right] / e_{1}$.

By this operation, the effect of the target's rotation (parameter $e_{2}$ ) is reduced to a shift of the function $\mathrm{P}\left(\mathrm{x}_{4}{ }_{4}, \mathrm{y}_{4}{ }_{4}\right)$ along the axis $\mathrm{x}_{4}$.

At the eighth stage, the parameter value $e_{2}$ is calculated based on component $x_{40}\left(e_{2}\right)$ by phase extraction [13]. 


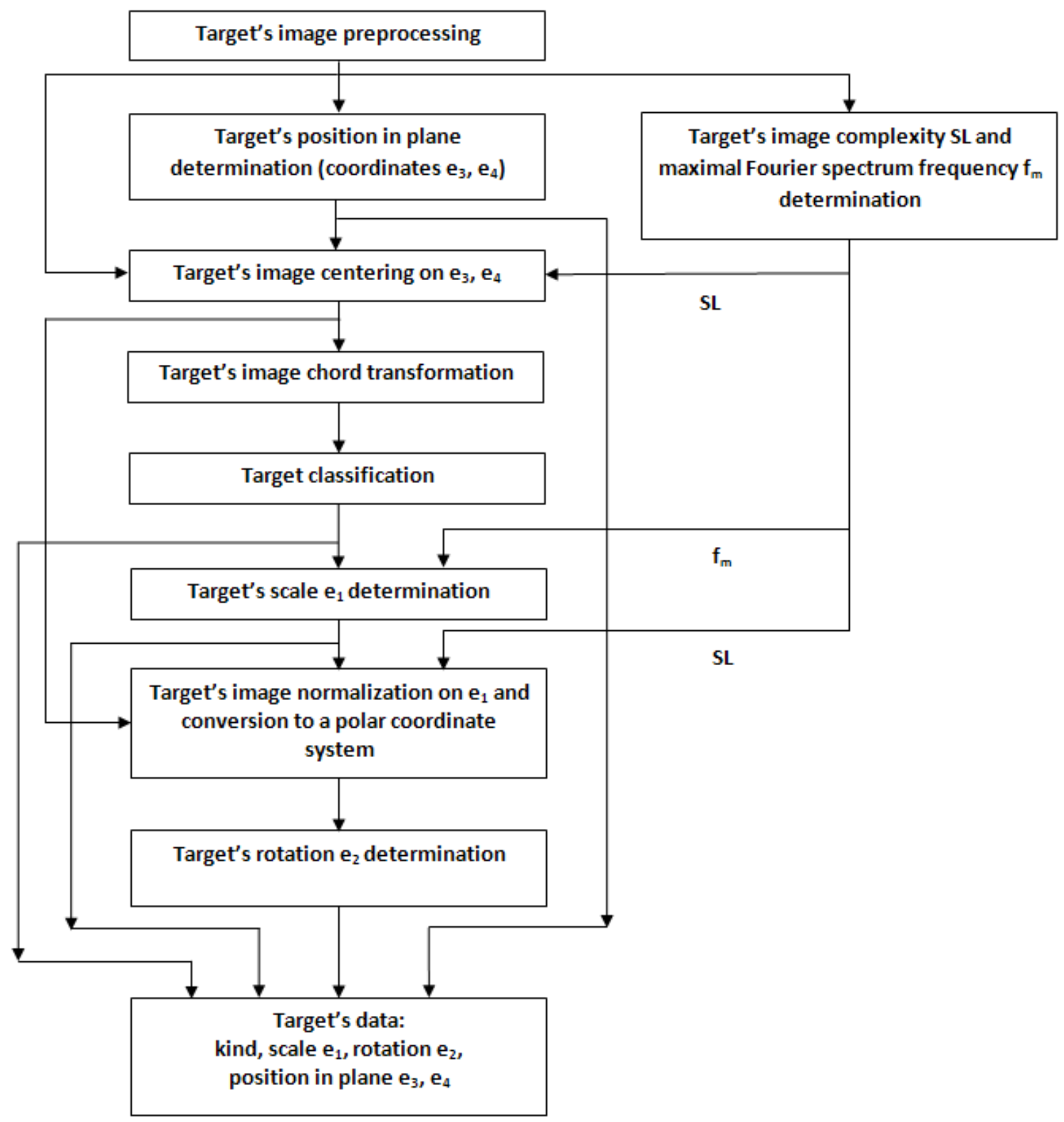

Figure 1. The method TRM1 of target recognition.

As a result, it will be obtained the data regarding the kind of the target, his scale (parameter $\mathrm{e}_{1}$ ), rotation (parameter $\mathrm{e}_{2}$ ), and position in the plane (parameters $\mathrm{e}_{3}, \mathrm{e}_{4}$ ).

\section{Method TRM2 of target recognition}

The method TRM2 of target recognition use next operations: PP-F-P-N-CT-C-N2-S,R (Figure 2) By this method, the data processing on stages 1 - 5 is the same as at the method M1.

At the sixth stage, the centered target's image will be converted to the log-polar coordinate system:

$$
P\left(x^{\prime}{ }_{2}, y_{2}^{\prime}\right)=P\left(x_{2}, y_{2}, e_{1}, e_{2}\right) \rightarrow P\left(x^{\prime}, y_{4}^{\prime}\right)=P\left[x_{4}+x_{40}\left(e_{1}\right), y_{4}+y_{40}\left(e_{2}\right)\right],
$$

where $\mathrm{x}_{4}=\operatorname{arctg}\left(\mathrm{y}_{2} / \mathrm{x}_{2}\right), \quad \mathrm{y}_{4}=\ln \left[\left(\mathrm{x}_{2}{ }^{2}+\mathrm{y}_{2}{ }^{2}\right)\right] / 2, \quad$ and $\mathrm{x}_{40}\left(\mathrm{e}_{1}\right), \mathrm{y}_{40}\left(\mathrm{e}_{2}\right)$ are the constants, determined by parameters $\mathrm{e}_{1}$ and $\mathrm{e}_{2}$ respectively. 
Wherein, the effects of the target scaling (parameter $\mathrm{e}_{1}$ ) and rotation (parameter $\mathrm{e}_{2}$ ) are reduced to shifts of the function $\mathrm{P}\left(\mathrm{x}_{4}^{\prime}, \mathrm{y}_{4}{ }_{4}\right)$ along the axis $\mathrm{x}_{4}$ and $\mathrm{y}_{4}$ respectively.

On the final, seventh stage, the target's scale $e_{1}$ and rotation $e_{2}$ determination will take place based on the operation of correlation, realized between the target's function $\mathrm{P}\left(\mathrm{x}_{4}{ }_{4}, \mathrm{y}_{4}{ }_{4}\right)$ and standard target's function $\mathrm{P}_{5}\left(\mathrm{x}_{4}, \mathrm{y}_{4}\right)$, the class of which was established on the stage of classification:

$$
U(x, y)=\max \left\{\iint P\left(x^{\prime}{ }_{4}, y^{\prime}{ }_{4}\right) P_{5}\left(x_{4}, y_{4}\right) d x_{4} d y_{4}\right.
$$

In comparison with method TRM1, in the method TRM2 is using another kind of the target's image conversion - to the log-polar coordinate system and the parameters of scale $\mathrm{e}_{1}$ and rotation $\mathrm{e}_{2}$ are determined in one stage only using the correlation approach.

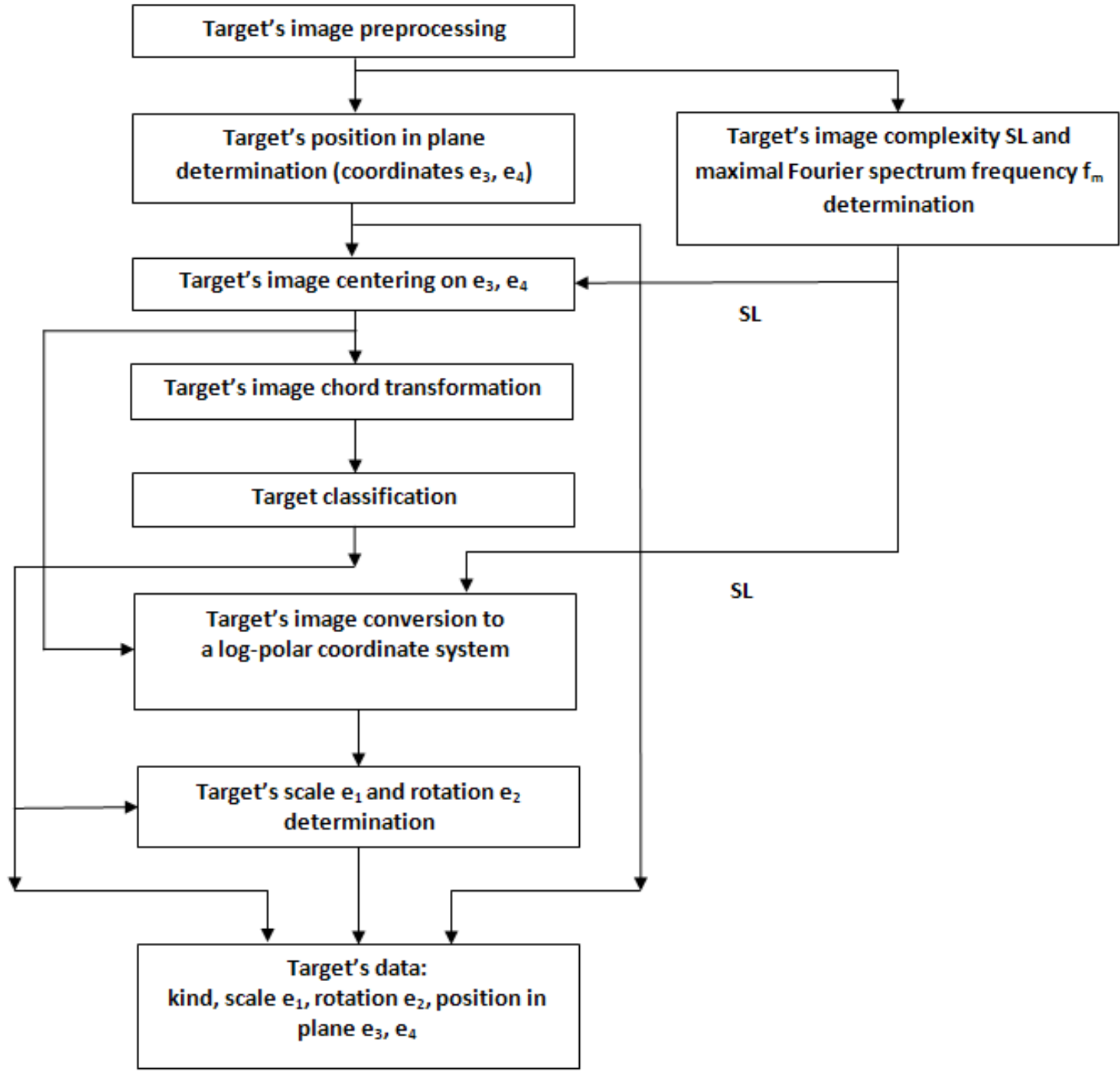

Figure 2. The method TRM2 of target recognition.

\section{Method TRM3 of target recognition}

The method TRM3 of target recognition suppose the next operations: PP-P,N3-CT1C-N4-S,R (Figure 3) The first stage of method TRM3 is the same as in the previous methods.

At the second stage, the target's position in the plane (parameters $e_{3}, e_{4}$ ) is calculated and the Fourier spectrum of the target's image is obtained:

$$
P\left(x^{\prime}, y^{\prime}\right)=P\left(x+e_{3}, y+e_{4}, e_{1}, e_{2}\right) \rightarrow\left|F T\left\{P\left(x^{\prime}, y^{\prime}\right)\right\}\right|^{2}=P\left(x^{\prime}{ }_{1}, y_{1}^{\prime}\right)=P\left(x_{1}, y_{1}, e_{1}, e_{2}\right)
$$


By this operation, the target's image is centered on parameters $e_{3}$ and $e_{4}$. The complexity $S L$ of the function $P\left(x^{\prime}, y^{\prime}\right)$ is determined.

On the third stage will be realized Central Image Chord Transformation (CICT) of the function $P\left(x^{\prime}{ }_{1}, y^{\prime}{ }_{1}\right)$ :

$$
\mathrm{P}\left(\mathrm{x}^{\prime}{ }_{1}, \mathrm{y}^{\prime}{ }_{1}\right) \rightarrow \mathrm{T}\left\{\mathrm{P}\left(\mathrm{x}^{\prime}{ }_{1}, \mathrm{y}^{\prime}{ }_{1}\right)\right\}=\mathrm{P}\left(\mathrm{x}^{\prime}{ }_{2}, \mathrm{y}^{\prime}{ }_{2}\right),
$$

where $\mathrm{T}\{\ldots\}$ - the operation of CICT. The vector $\mathbf{v}$ of the target's features will be formed.

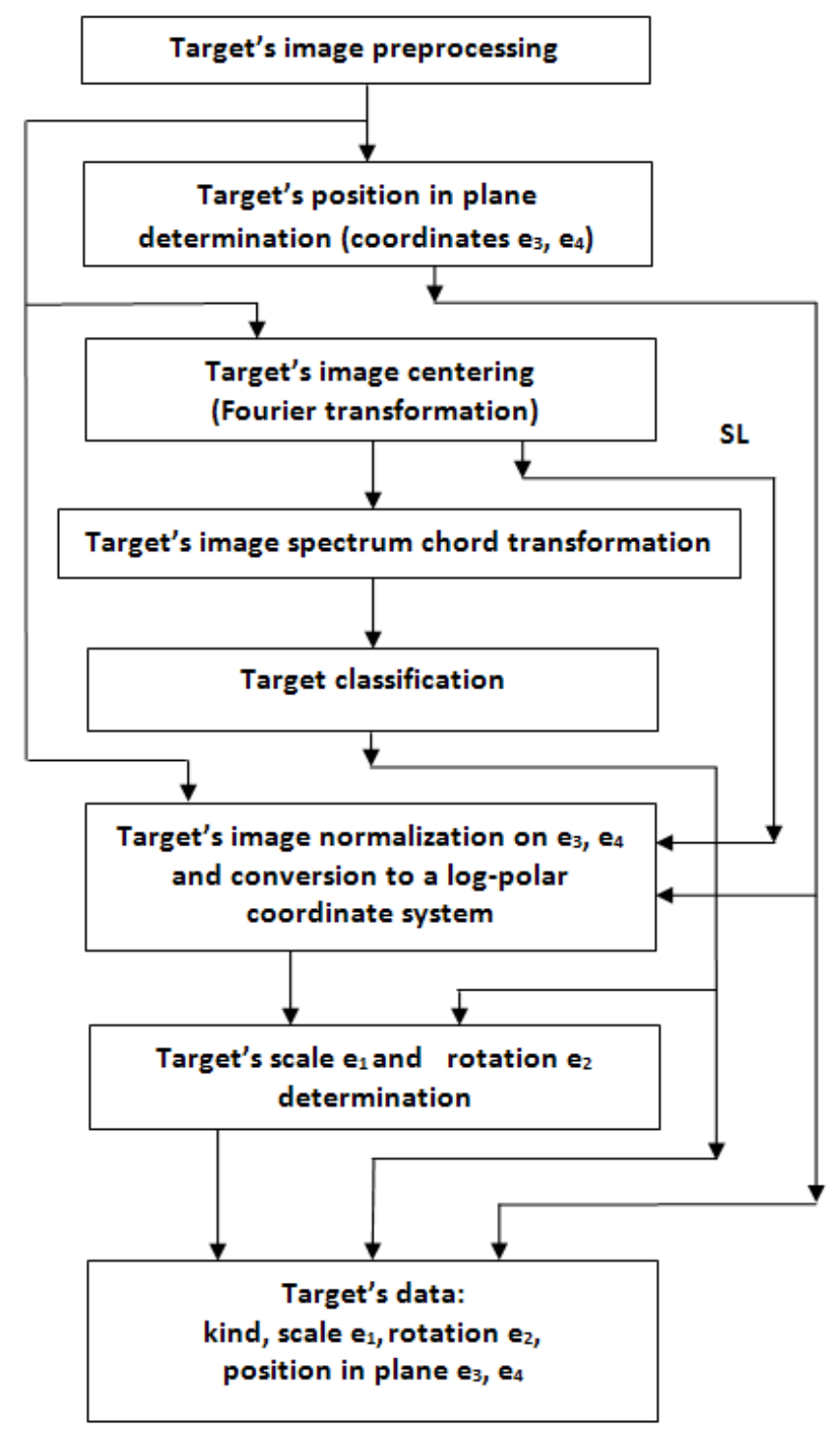

Figure 3. The method TRM3 of target recognition.

At the same time, the function $\mathrm{P}\left(\mathrm{x}^{\prime}, \mathrm{y}^{\prime}\right)$ is centered based on the parameters $\mathrm{e}_{3}, \mathrm{e}_{4}$, and parameter SL, and is converted to the log-polar coordinate system:

$$
P\left(x^{\prime}, y^{\prime}\right)=P\left(x+e_{3}, y+e_{4}, e_{1}, e_{2}\right) \rightarrow P\left(x^{\prime}{ }_{3}, y^{\prime}\right)=P\left[x_{3}+x_{30}\left(e_{2}\right), y_{3}+y_{30}\left(e_{1}\right)\right],
$$

were $x_{3}^{\prime}=\operatorname{arctg}\left(y^{\prime \prime} / x^{\prime \prime}\right), y^{\prime}{ }_{3}=\ln \left[\left(x^{\prime \prime}\right)^{2}+\left(y^{\prime \prime}\right)^{2}\right] / 2$, and $x^{\prime \prime}=x^{\prime}-e_{3}, y^{\prime \prime}=y^{\prime}-e_{4}$.

So, the function $P\left(x_{3}^{\prime}, y_{3}^{\prime}\right)$ will not be influenced by parameters $e_{3}, e_{4}$. The influence of the parameters $e_{1}$ and $e_{2}$ will be reduced to the shifts of the function $P\left(x^{\prime}{ }_{3}, y_{3}^{\prime}\right)$ on coordinates 
$x_{3}^{\prime}, y_{3}^{\prime}$. The values $x_{30}\left(e_{2}\right)$ and $y_{30}\left(e_{1}\right)$ are the constants determined by parameters $e_{2}$ and $e_{1}$ respectively.

At the fourth stage, the target recognition based on the processing of the vector $\mathbf{v}$ will be made.

On the fifth stage, the target's scale $e_{1}$ and rotation $e_{2}$ are calculated based on the target's kind determined previously and calculation of the correlation function:

$$
U\left(x_{4}, y_{4}\right)=\max \left\{\iint P\left(x_{3}^{\prime}, y_{3}^{\prime}\right) P_{5}\left(x_{3}, y_{3}\right) d x_{3} d y_{3}\right\}
$$

were $\mathrm{P}_{\mathrm{s}}\left(\mathrm{X}_{3}, \mathrm{y}_{3}\right)$ is the target's standard function.

The main differences of the method TRM3 in comparison with previous methods consist in the fact, that the operations of chord transformation and classification are based on the target's image Fourier spectrum processing on stages 3 and 4, and in the realization of the combined operation of the target's image normalization on the parameters $\mathrm{e}_{3}$ and $\mathrm{e}_{4}$ and conversion to the log-polar coordinate system (stage 3).

\section{Method TRM4 of target recognition}

The method TRM4 of target recognition suppose the realization of the next set of operations: PP-N4-CT1-C-S-N2-R-N6-P (Figure 4) The first stage of the method TRM4 is the same as in the previous methods.

At the second stage, the Fourier spectrum of the target's image is formed:

$$
P\left(x^{\prime}, y^{\prime}\right)=P\left(x+e_{3}, y+e_{4}, e_{1}, e_{2}\right) \rightarrow\left|F T\left\{P\left(x^{\prime}, y^{\prime}\right)\right\}\right|^{2}=P\left(x^{\prime}{ }_{1}, y^{\prime}{ }_{1}\right)=P\left(x_{1}, y_{1}, e_{1}, e_{2}\right),
$$

were $\mathrm{FT}\{\ldots\}$ - is Fourier transform operation.

As a result of this operation, the target's image is centered on parameters $e_{3}$ and $e_{4}$ Based on the function $P\left(x_{1}^{\prime}, y_{1}^{\prime}\right)$, the maximum frequency $f_{m}$ and the of the target's image $P\left(x^{\prime}, y^{\prime}\right)$ complexity $S L$ are determined.

On the third stage will be realized Central Image Chord Transformation of the function $P\left(x^{\prime}{ }_{1}, y^{\prime}{ }_{1}\right)$ :

$$
\mathrm{P}\left(\mathrm{x}_{1}{ }_{1}, \mathrm{y}^{\prime}{ }_{1}\right) \rightarrow T\left\{\mathrm{P}\left(\mathrm{x}^{\prime}{ }_{1}, \mathrm{y}^{\prime}{ }_{1}\right)\right\}=\mathrm{P}\left(\mathrm{x}^{\prime}{ }_{2}, \mathrm{y}^{\prime}{ }_{2}\right),
$$

The vector $\mathbf{v}$ of features will be calculated based on the function $\mathrm{P}\left(\mathrm{x}_{2}^{\prime}, \mathrm{y}_{2}{ }_{2}\right)$.

At the fourth stage, the target recognition will be made based on the vector $\mathbf{v}$ processing.

On the fifth stage, the target's scale $\mathrm{e}_{1}$ is determined as

$$
e_{1}=f_{m s} / f_{m},
$$

where $f_{m s}$ is the Fourier spectrum's maximum frequency of the standard target, the class of which was determined on the previous stage.

On the sixth stage, the target's image spectrum will be normalized on scale $e_{1}$ and transformed to a polar coordinate system:

$$
P\left(x_{1}^{\prime}, y_{1}^{\prime}\right)=P\left(x_{1}, y_{1}, e_{1}, e_{2}\right) \rightarrow P\left(x_{3}^{\prime}, y_{3}^{\prime}\right)=P\left[x_{3}+x_{30}\left(e_{2}\right), y_{3}\right],
$$

were $x_{3}=\operatorname{arctg}\left(y{ }_{1} / x{ }_{1}\right), y_{3}=\left[\left(x{ }_{1}\right)^{2}+\left(y{ }_{1}\right)^{2}\right]^{1 / 2}$ and $x{ }_{1}=x_{1}, y{ }_{1}=y_{1} / e_{1}$

At the seventh stage, the target's rotation $e_{2}$ is determined based on the value $x_{30}\left(e_{2}\right)$ extraction.

At the eighth stage, the target's image normalization on parameters $\mathrm{e}_{1}$ and $\mathrm{e}_{2}$ is made: 


$$
P\left(x^{\prime}, y^{\prime}\right)=P\left(x+e_{3}, y+e_{4}, e_{1}, e_{2}\right) \quad \rightarrow \quad P\left(x_{4}^{\prime}, y_{4}^{\prime}\right)=P\left(x_{4}+e_{3}, y_{4}+e_{4}\right)
$$

were $x^{\prime}{ }_{4}=\left[x^{\prime} \cos \left(-e_{2}\right)-y \sin \left(-e_{2}\right)\right] / e_{1}, y^{\prime}{ }_{4}=\left[x^{\prime} \sin \left(-e_{2}\right)+y \cos \left(-e_{2}\right)\right] / e_{1}$.

In the ninth stage, the target's parameters $e_{3}, e_{4}$ will be determined via the correlation function calculation:

$$
\mathrm{U}\left(\mathrm{x}_{5}, \mathrm{y}_{5}\right)=\max \left\{\iint \mathrm{P}\left(\mathrm{x}_{4}^{\prime}, \mathrm{y}_{4}{ }_{4}\right) \mathrm{P}_{5}\left(\mathrm{x}_{4}, \mathrm{y}_{4}\right) \mathrm{dx} \mathrm{x}_{4} \mathrm{dy} \mathrm{y}_{4}\right.
$$

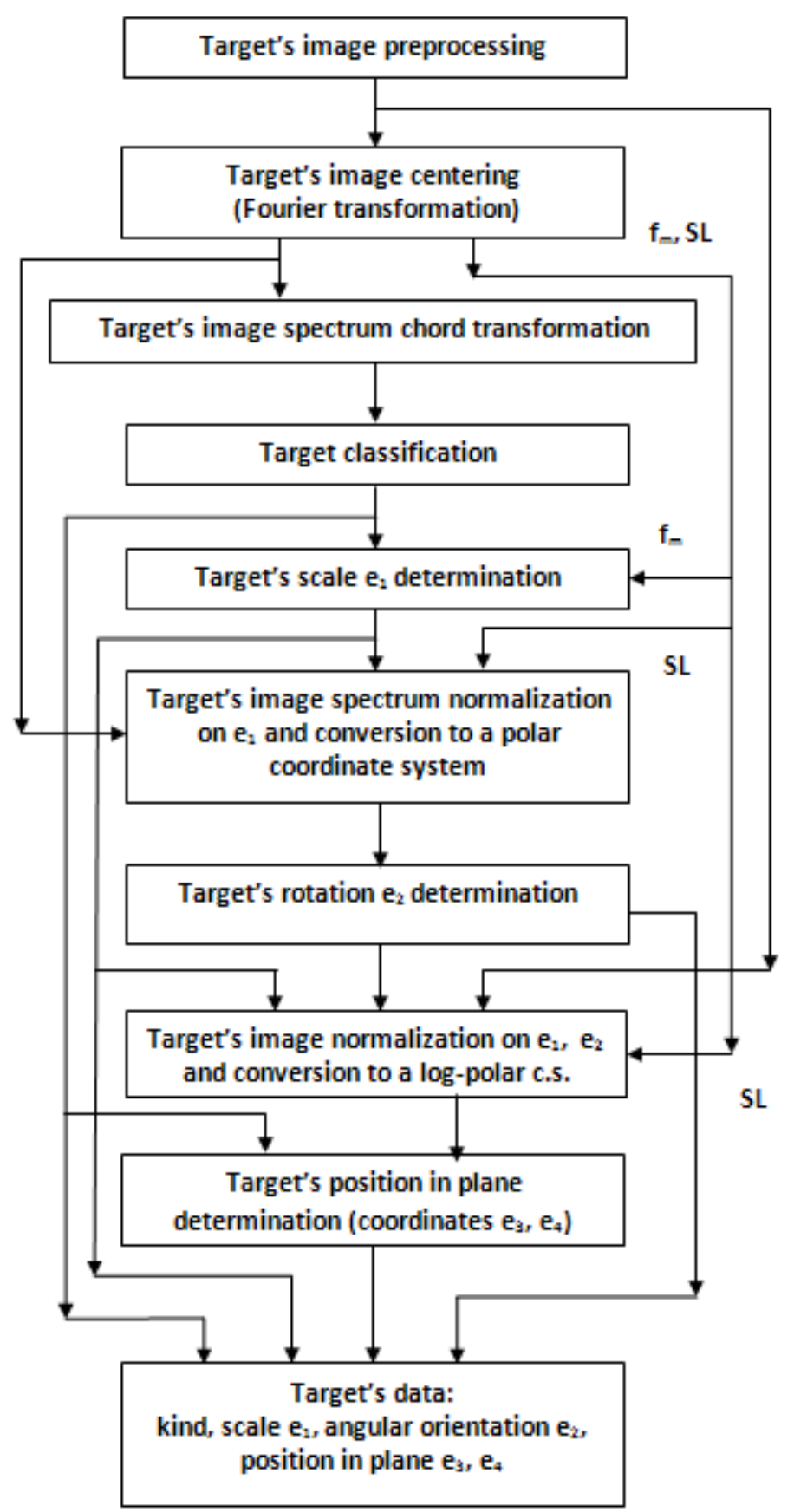

Figure 4. The method TRM4 of target recognition.

The main differences between method TRM4 and previous methods consist in the following. 1. The target is classified, after which there are determined all his parameters. 2. Target is classified and parameters $e_{1}$ and $e_{2}$ are determined based on the target's image Fourier spectrum. 


\section{Comparison of the target's recognition methods}

The elaborated methods permit the classification of the targets and determination of their parameters - position in the plane, scale, and angular rotation. The comparative data regarding target's recognition methods TRM1 $\div$ TRM4 are presented in Table 1 and Figure 5 .

Table 1

Target's recognition methods comparative data

\begin{tabular}{|c|c|c|c|c|c|}
\hline & $\begin{array}{l}\text { Recognition } \\
\text { method }\end{array}$ & TRM1 & TRM2 & TRM3 & TRM4 \\
\hline 1. & $\begin{array}{l}\text { Sequences of } \\
\text { operations }\end{array}$ & $\begin{array}{c}\text { PP-F-P-N-CT- } \\
\text { C-S-N1-R }\end{array}$ & $\begin{array}{c}\text { PP-F-P-N-CT- } \\
\text { C-N2-S,R }\end{array}$ & $\begin{array}{l}\text { PP-P,N3-CT1- } \\
\text { C-N4-S,R }\end{array}$ & $\begin{array}{l}\text { PP-N3-CT1-C- } \\
\text { S-N5-R-N6-P }\end{array}$ \\
\hline 2. & Kind of method & $\begin{array}{c}\text { Parameters - } \\
\text { Classification- } \\
\text { Parameters }\end{array}$ & $\begin{array}{c}\text { Parameters - } \\
\text { Classification- } \\
\text { Parameters } \\
\end{array}$ & $\begin{array}{c}\text { Parameters \| } \\
\text { Classification- } \\
\text { Parameters } \\
\end{array}$ & $\begin{array}{l}\text { Classification- } \\
\text { Parameters }\end{array}$ \\
\hline 3. & $\begin{array}{l}\text { Processing of } \\
\text { the: }\end{array}$ & Target's image & Target's image & $\begin{array}{c}\text { Target's image } \\
\text { Fourier } \\
\text { spectrum }\end{array}$ & $\begin{array}{c}\text { Target's image } \\
\text { Fourier } \\
\text { spectrum }\end{array}$ \\
\hline 4. & $\begin{array}{l}\mathrm{Nr} \text { of processing } \\
\text { stages }\end{array}$ & 8 & 7 & 5 & 7 \\
\hline 5. & $\mathrm{Nr}$ of operations & 9 & 8 & 6 & 9 \\
\hline 6. & $\begin{array}{c}\text { Nr of image } \\
\text { normalization's } \\
\text { operations }\end{array}$ & 2 & 2 & 2 & 3 \\
\hline 7. & $\begin{array}{l}\text { Nr of the } \\
\text { operations } \\
\text { realized in } \\
\text { parallel }\end{array}$ & 2- P, F & $\begin{array}{c}4: 2-P, F ; 2-S, \\
R\end{array}$ & $\begin{array}{c}\text { 6: } 2 \text { - P, F; } 2 \text { - } \\
\text { N5, CT; and } 2 \text { - } \\
\text { S, R }\end{array}$ & - \\
\hline 8. & $\begin{array}{c}\text { Determination } \\
\text { of the } \\
\text { parameters S } \\
\text { and R }\end{array}$ & Consecutive & Parallel & Parallel & Consecutive \\
\hline 9. & $\begin{array}{l}\text { Target's rotation } \\
\text { determination } \\
\text { approach }\end{array}$ & $\begin{array}{c}\text { Faze } \\
\text { extraction }\end{array}$ & Correlation & Correlation & Faze extraction \\
\hline
\end{tabular}

The comparison of the elaborated target recognition methods shows the following.

1. Depending on the consequence of the operations of the target classification and his parameters determination, the methods can be divided into 2 groups - "Parameters Classification - Parameters" (methods TRM1 $\div$ TRM3) and "Classification - Parameters" (method TRM4).

2. The methods TRM1 and TRM2 are based on the processing of the target's image, and methods TRM3 and TRM4 - on the processing of the target's image Fourier spectrum.

3. The methods TRM3 and TRM4 don't need the preliminary determination of the target's position in the plane to center the target's image.

4. Method TRM3 is characterized by minimal nr. of the processing stages ( 5 stages) and maximal $\mathrm{nr}$. of operations realized in parallel (6 operations).

5. Utilization of the correlation approach at the target's scale and rotation calculation permits us to determine these parameters in parallel. 
6. Method TRM1 needs the biggest nr of processing stages (8), and methods TRM1 and TRM4 need the biggest $\mathrm{nr}$ of processing operations (9)

7. Method TRM4 needs the biggest $\mathrm{nr}$ of the target's image normalization operations (3).

8. Methods TRM2 and TRM3 suppose the determination of the target's scale and rotation in parallel, using a correlation approach.

9. Methods TRM1 and TRM4 suppose the determination of the target's rotation based on the faze extraction approach.

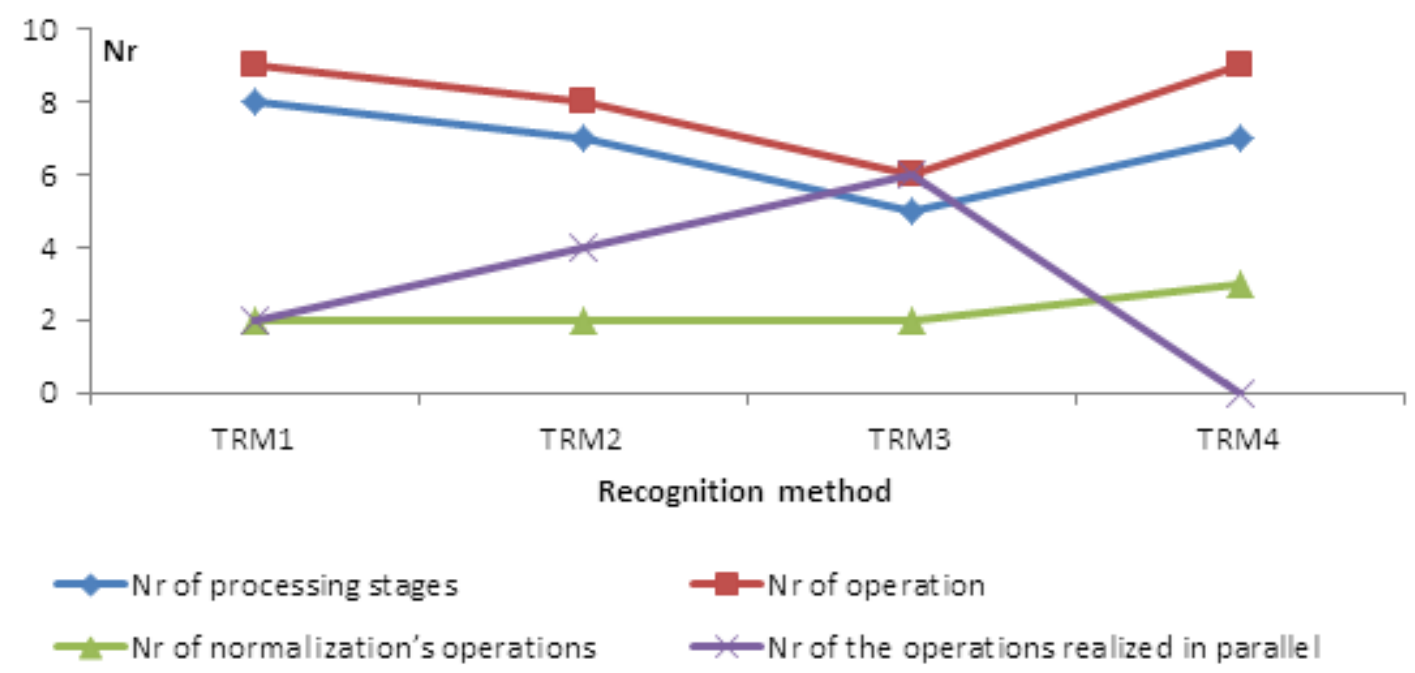

Figure 5. Graphical presentation of the target's recognition methods comparative data.

\section{Conclusions}

The new methods of the target recognition are described being based on the Central Image Chords Transformation.

Depending on the consequence of the operations of the targets classification and their parameters determination, the methods can be divided into 2 groups - "Parameters Classification - Parameters" (methods TRM1 $\div$ TRM3) and "Classification - Parameters" (method TRM4).

The methods TRM1 and TRM2 are based on the processing of the target's images, and methods TRM3 and TRM4 - on the processing of the target's image Fourier spectrum.

Method M3 is characterized by minimal nr. of the processing stages and maximal $\mathrm{nr}$. of operations realized in parallel. The methods TRM3 and TRM4 don't need the preliminary determination of the target's position in the plane to center the target's image.

Method TRM1 needs the biggest nr of processing stages. Method TRM4 needs the biggest $\mathrm{nr}$ of the processing operations and the target's image normalization operations.

Methods TRM2 and TRM3 suppose the determination of the target's scale and rotation using the correlation approach, which permits the determination of these parameters in parallel.

Methods TRM1 and TRM4 suppose the determination of the target's rotation based on the faze extraction approach. 


\section{References}

1. Jin L., Qinzhang Y., Guibin C. Infrared ship target detection based on the combination of Bayesian theory and SVM. In: Proc. SPIE 11429, 2019.

2. Ciocoiu I. B. Invariant pattern recognition using support vector data description and tangent distance. In: Proc. of the Romanian Academy, Ser. A, Vol. 20, Nr. 2, pp. 197-204, 2019.

3. Uchaev D., Malinnikov V. Spectral-spatial classification of hyperspectral images based on multifractal features. In: Proc. SPIE 11533, 2020.

4. Senlin Y., Jing S., Yingni D. Dangerous object detection by deep learning of convolutional neural network. In: Proc. SPIE 11427, 2020.

5. Garcia-Salgado B., Ponomaryov V. Parallel artificial neural networks using wavelet-based features for classification of remote-sensing hyperspectral images. In: Proc. SPIE 11401, 2020.

6. Tuama A., Abdulrahman H., Magnier B. Integrated convolutional neural network model with statistical moments layer for vehicle classification. In: Proc. SPIE 11433, 2019.

7. Benouini R., Batioua I., Zenkouar K. Fractional-order orthogonal Chebyshev moments and moment Invariants for image representation and pattern recognition. In: Pattern Recognition, Vol. 86, February, pp. 332-343, 2019.

8. Spiliotis I., Karampasis N., Boutalis Y. Fast computation of Hahn moments on gray images using block representation. In: Journal of Electronic Imaging, Vol. 29, Issue 1, 2020.

9. Perzhu V., Gurau A., Saranciuc D. The optical-electronic pattern recognition system based on the image's logarithmic chord transformation method. In: Optical Pattern Recognition VIII - David P. Casasent, Tien-Hsin Chao, Eds. / Proc SPIE Vol.3073, pp.332-342 (1997). ISBN 9780819424884.

10. Perju V., Cojuhari V. Central and logarithmic central image chord transformations for invariant object recognition. In: Journal of Engineering Science. 2021, Vol. XXVIII, no. 1 (2021), pp. 38 - 46 ISSN 2587-3474/EISSN 2587-3482. https://doi.org/10.52326/jes.utm.2021.28(1).03.

11. Duda R. O., Hart P. E., Stork D. G. Pattern Classification. Wiley Interscience, 2000.

12. Perju V., Casasent D. The investigation of the Fourier spectrum-based image complexity metrics for recognition applications. In: Proc. SPIE 8398, 2012.

13. Katys G.P., Perju V.L., Rotary S.L. Methods and computer means of image processing. Stiinta, Chisinau, 1991. 